\title{
RECOGNIZED GEOHERITAGE \& GEOTOURISM SITES IN INDIA
}

\author{
Punyakrit Singh Ranawat \\ PGDM Student \\ Welingkar Institute of Management, Mumbai
}

\begin{abstract}
India has a lot to showcase in the field of geological and geomorphological features of its vast landscape. Geoheritage sites are geological areas of scientific, cultural and educational value. But the development of these sites and this field hasn't been the significant when compared others fields. India remains poorly documented, suffers constant damages to its geological wealth and doesn't realise the economic contribution, which can arise from its geological wealth. Geoheritage of our country presents an economical, sociocultural, educational and a unique opportunity which everyone can reap. The right 'storytelling' for these sites can do the trick. This paper presents to its readers the various 'Recognized Geoheritage Sites', often referred to as 'National Geological Monuments' (NGMs) in our country and the reality of these sites today. Local administration goes a long way in the improvement of these sites and the ways in which the citizens can help in the maintenance/ upkeep of these sites. But at a national level, we need more resource allocation for these sites to become 'presentable' as tourism hotspots. The Geological Survey of India (GSI) should look more keenly at this type of tourism, which is called 'Geotourism'. Converting these sites into 'Geoparks', a UNESCO initiative for development and projection of these sites for the world, can definitely bring more light to these sites and to this field. While, many countries are adding Geoparks by the year, India hasn't been successful in this endeavour. The urge for the reader is hence to understand the situation of these sites and then do their bit, perhaps as a citizen, a leader, a government official or just a visitor. It is our responsibility to maintain and furbish these sites of immense importance not just to the current but the future generations as well.
\end{abstract}

Keywords - Geoheritage, Geoparks, Geotourism, National Geological Monuments (NGMs), UNESCO, Geological Survey of India (GSI), Storytelling

\section{INTRODUCTION}

Geoheritage sites are packed with aesthetic appeal, able to promote local tourism as well as regional tourism. These are critically important in advancing the knowledge about natural phenomenon like climate changes, soil processes, mineral processes, groundwater supply changes, hazards, energy supply levels, environmental changes and the evolution of life itself. Having said this, these sites offer a high potential for educational school trips, economic support for the local communities and recreational uses. In all, they pack a host of benefits that we are yet to explore.

\section{GEOTOURISM}

National Geographic defines Geotourism as, "Tourism that sustains or enhances the distinctive geological character of a place- its environment, heritage, aesthetics, culture and the well-being of its residents" (National Geographic et al., 2020). The Indian subcontinent is endowed with a rich history, prominent physical hallmarks and a rich cultural heritage. In India the responsibility of protection and promotion of the geological sites lies with Geological Survey of India (GSI) which was founded in 1851 and is a part of the Government of India Ministry of Mines department.

The thought for this paper is in line with the demarcation of 26 NGMs in India by the GSI. The National Geological Monuments (NGMs) in India are sites with distinct physical attributes of scientific importance. These sites at the same time are perfect to be converted into Geoparks, which then can be recognized as 'UNESCO Global Geoparks'. This international recognition can help propel our geological wealth in the right direction and on a more international scale.

\section{RECOGNIZED GEOHERITAGE SITES (NGMS)}

\section{Natural Arch, Tirumala Hills, Andhra Pradesh}

Natural arch, Tirumala hills, is a notified national geo-heritage monument of India. It is a distinct geological feature situated about $1 \mathrm{KM}$ north of the hills of Tirumala temple, near the Chakra Teertha Stan (place) in the state of Andhra Pradesh. The arch is also called as 'Silanthoranam' in Telugu (INTACH et al., 2016). The Arch is 8 meters in width and 3 meters in height and is naturally formed in the quartzite(s) of Cuddpah Supergroup of middle to upper Proterozoic (1600 to $570 \mathrm{Ma}$ ) all because of the massive natural erosion that took place over the due course of time. The geological age of the rock arch is assessed to be at 2.5 million years. The technical term for this rare geological fault is 'Eparchean Unconformity'. Natural 
arches like these are formed in areas with cliffs that are subjected to erosion from the nearby seas, river and water bodies. For over thousands of years, the Natural Arch at Tirumala Hills has been subject to weathering agents like wind and water and thus this marvel has been carved out of the quartzite rock. During sunrise this place is often termed as, 'Ethereally Beautiful' and the visitor can certainly enjoy this view.

2. Eparchaean Unconformity, Tirumala Hills, Chitoor District, Andhra Pradesh

This Geoheritage site is enclosed in the Eastern Ghats in the Tirupati Valley and is situated 850 meters above the mean sea level. The 'Eparchaean Unconformity' of the Chittor district is also known as the 'Tirupati Eparchaean Unconformity' and is a major discontinuity of stratigraphic significance (INTACH et al., 2016). It represents a period of time when the rapid changes in the structure of our planet Earth were a common thing and sudden changes in an area due to the extreme forces of nature would give birth to such a discontinuity. This unconformity forms a specific boundary between the 'Proterozoic Nagari Quartzites' and the 'Archaean granite'.

The unconformity is very important as the time gap questions that it poses to the geologists studying the area is very significant. The Cuddappah Supergroup was formed nearly 1600 million years ago which essentially comprises of the sedimentary rocks, whereas the Arhaean rocks which comprise of various granites, gneisses and dolerites are more than 2300 million years old. This time lag of $800 \mathrm{Ma}$ is quite significant in the creation of the Earth's crust.

\section{Bedded Barytes, Mangampeta, Cuddapah District (YSR District), Andhra Pradesh}

This barite deposit is considered to be one of the largest barite deposits in the world (Karam et al., 1997). Technically penning it down this geological site was formed by precipitation from various volcanic vapours under submarine conditions and sub-aerial showering of ash and molten barite lapilli. The deposits appear largely in the Cuddapah Supergroup but precisely occur in the Pullampet formation of the Nallamalai Group. The lower beds of the Mangampeta barite deposits are of most superior grade quality of barite that there is. The lower beds tend to occur in the form of Barium sulphate. These barite deposits as mentioned before are considered to be the single largest accumulation of barite in the world. With 74 million tonnes of barite that is deposited in this site the quantity is equal to $98 \%$ of barite deposit of India and nearly $28 \%$ barite deposit of the world. While the visitors can certainly be amazed looking at the largest barite deposit of India, the one immediate threat to this place is illegal mining.

\section{Erra Matti Dibbalu, Visakhapatnam, Andhra Pradesh}

The site is located on the outskirts of the large city of Visakhapatnam. The site is also known as the 'Red Sand Hills'. The site lies on the coast of the Bay of Bengal and stretches $4 \mathrm{KMs}$ in length and $2 \mathrm{KMs}$ in width and is bounded by two streams on its North-west and South-west frontiers namely Chittigadda and Peddagadda. This marvel is created by natural weathering processes. Over millions of years the sea levels rose and fell and the sand was constantly exposed to the water and a harsh warmth of the sun, due to which the sand baked and baked and got its red colour. Any visitor will be relieved looking at the beautiful red sand dunes all around them and sitting and just thinking about nature's marvels. This spot of a local picnic spot as well. The eminent threat to this site is currently posed by the expansion of the city, due to which a lot of the sand dunes have been lost to people who want to build homes close to the bay.

\section{The Marine Gondwana Fossil Park, Manendragarh, Sarguja District, Chhattisgarh}

The Marine Gondwana Fossil Park at Manendragarh, Sarguja District, Chhattisgarh is spread across an area of 16200 sq. meters. The park is a unique marine fossil park. The land contains the exposure of fossiliferous marine Permian (280$240 \mathrm{Ma}$ ), Carbonaceous Shale Rocks of Talchir Formation belonging to the Gondwana Supergroup. The formation has an elongated length of $1 \mathrm{KMs}$ upstream to the point of confluence of the Hasdeo river and the Hasia Nala.

In the year 2014, the government allocated a sum of 17.5 lakhs to set up the fossil park to help conserve the endangered flora and fauna of this site. The government has also taken measure to bring down the cross border illegal trade of these fossils. The fossil park is also without any doubts rich in the marine fauna that can be easily a tourist attraction parameter. The marine fauna is dominant in the pelecypods or also the lamellibranchs like Eurydesma and Aviculopecten within shale. It also has Bryozoans, Crinoids and forminifers.

\section{Eddy Current Markings, Kadana Village, Panchmahal District, Gujarat}

Millions of years ago, during the Aravalli Orogeny the incompetent (also the soft \& fragmented) sedimentary rocks got transformed into metamorphic rocks. This orogeny movement of metamorphic rocks imposed a lot of stress and this stress hence generated cross-stratification, horizontal stratification, planar cross bedding, flute and groove marks on the rocks. These markings on the rocks that there are on the surface made up of sandstone-quartzite from Upper Aravalli Lunavada group (The Precambrian Proterozoic) are one of the most marvellous and rare markings that can depict the timeframe or evolution of the ranges of Aravalli. This site as mentioned before is of strategic importance of the study of evolution in the Upper Ranges of Aravalli. The entire area is 
made up of sedimentary and metamorphic rocks, but all of them have one thing in common, the rocks have circular markings on them, which it is dated to be preserved on these rocks since the Precambrian Era. Even in this site, road constructions and housing and development in the nearby areas do pose a threat on the markings on the rocks. This place hasn't seen much development since 1976.

\section{Siwalik Fossil Park, Suketi, Himachal Pradesh}

The Siwalik Fossil Park is also known as the Suketi Fossil Park and is nested in the beautiful picturesque of the foothills of Himachal Pradesh. Himachal Pradesh is rich that way as it has these 2.5-million-year-old fossils from the Siwaliks. The entire area is spread over $1.5 \mathrm{Km}^{2}$ in the Markanda valley of Sirmaur in Himachal Pradesh. The park displays life-size fiberglass models of six of the prehistoric animals that were present in the area about 1.5 million years ago. The six animals consist of the Giant Land Tortoise, The Gharial, The Four Horned Giraffe, The Sabre Toothed Tiger, The Large Tusked Elephant and The Hipoploamid. The site has developed to a panorama of Plio Pleistoscene period $(\mathrm{Ca}$ 2.5million years) through massive afforestation. Another reason for the development of the park apart from educating the common masses was to educate the historians and geologists as well of the pre-historic period. The fossils that are found in this park are the richest of antiquities in the World and are absolutely rare.

\section{Plant Fossil bearing Inter-Trappean beds of Rajmahal Formation, Jharkhand}

Declared as an NGM in 2014, the site has important plant fossil formations. The Rajmahal hill range is also believed to be one of the oldest mountain ranges that there are, and it has fine fossil beds from the Jurassic age. With a great view of the traps the place is perfect for a picnic spot or a drive. The major threat faced by this region is of mining.

\section{Lalbagh Botanical Gardens, Bangalore, Karnataka}

Since 1889, Lalbagh Botanical Gardens has been a famous place for annual flower shows and hosts one of the largest collections of tropical flowers in the country. The annual shows happen on two different dates, one on the Republic Day (26th January) and other one on the Independence Day (15th August) each year. It also happens to be one of the biggest tourist attractions spots in Bengaluru. Lots of birds are attracted in the area because of the tropical plants, such as the Parakeets, Pond Heron, Crows, Myna, Brahimny Kites, Common Egrets, Kingfishers, Spotted Owlets, Spotted Kites, Spotted Pelicans, Ducks, Indian Cormorant, Purple Moor Hen and other birds as well. Hyder Ali was the original person who aided out the Glass House structure for the Lalbagh Botanical
Gardens (Vasudev et al., 1998; Venkataramaiah et al., 1998). A lot of additions to the total amounts of area of the botanical gardens were made in different years. Originally, the gardens spanned an area of 45 acres in 1874, and with subsequent additions over the decades, this has led to a total area of 240 acres of gardens today. The garden is open daily from 6 am in the morning to $7 \mathrm{pm}$ in the evening. And another good thing about the garden is that no entry fee is taken in between $7 \mathrm{am}$ to $9 \mathrm{am}$ in the morning and $5 \mathrm{pm}$ to $7 \mathrm{pm}$ in the evening because that is the time when most of the joggers, walkers, fitness enthusiasts come in the garden.

\section{St. Mary's Islands (Columnar Basaltic Lava), Udupi District, Karnataka}

Located in the district of Udupi in the state of Karnataka, the St. Mary's Island also known as the Coconut Island are four islands in the Arabian sea and are widely known for their distinctive formation in terms of geology and are also known for their naturally occurring design. Scientifically speaking the islands were formed due to sub-aerial sub-volcanic activities. This happened almost 88 million years ago, at the time when Madagascar was attached to India. Legend has it that it was in the year 1498 that Vasco da Gama first stepped foot in India after his journey from Portugal and the St. Mary's Islands were the first place of his arrival to our land. When he came to this spot, he put a cross on one of the islands and that's how the place got its name. The four islands are namely: Coconut island, North Island, South Island and Daryabahadurgarh Island. Spread across an area of 5.5 acres, the visitors can not only visit the place but take great walks in the area and enjoy breezes from the sea. The islands are a picturesque group and worth capturing. High tides along with poor disposal of waste and littering by visitors add to the threats list of this site.

\section{Pillow Lava, Maradihalli, Chitradurga District, Karnataka}

This pillow lave site is part of the Chitradurga schist belt of Dharwar group. Pillow lavas are formed when molten lava erupts under water itself and then solidifies in the form of a rough sphere or rounded pillow shaped structure. Due to the water, the lava solidifies so quickly that it leaves some discrete rounded bodies a few feet or less in size.

The pillow lava at the Chitradurga district is dated to be 2500 million years old.

Improper fencing leaves this site open to gathering of people, who often disrespect the place.

\section{Pyroclastic Rocks, Peddapalli, Kolar District, Karnataka}

The pyroclastic rocks are present in the peddapalli village of the kolar district of Karnataka. The term pyroclastic can be broken down into two words, 'Pyro' and 'Clastic'. Pyro stands 
for fire and clastic stands for rocks that are broken which means rocks that are broken down by fire. The pyroclastic rocks of peddapalli village are a set of welded agglomerates of very large fragments of granite, basalt, granite gneiss and also banded ferruginous quartzite all set in a matrix of ignimbrite. Many of these rocks are either angular in shape or are rounded in shape. Some of the rocks that are made up of the granite gneiss are as large as $80 \mathrm{~cm}$ in diameter. The signage board leading to this area isn't properly put up nor is it maintained. The site is used by villagers for open defecation and the water bodies near this site are also polluted because of human activities.

\section{Angadipuram Laterite Deposits, Malappuram District, Kerala}

The first account of this site was mentioned in the year 1807 by a famous surgeon, Dr Francis Hamilton, describing the qualities and various uses of this type of rock. Essentially Laterite is a soil and a type of rock that is very rich in aluminium and iron. The main regions where it is easily formed is the ones with a tropical wet environment but enough heat at the same time. Such conditions are there in Kerala; hence it has huge deposits of laterite in many parts of the state. Over the years, laterite has been used in many places. Be it the temples and the monuments, or being its ability to be semipermeable and porous and hence acting as a purifier of water in villages across India and laterite has also been used to remove phosphorous during sewage treatment processes. We know that rocks are mainly classified as sedimentary, igneous and metamorphic, but that's not the case for laterites. They fall outside the realms of this general classification and have been specially placed in the 'sedimentary residual product' category. It is because of its porous nature. The economic importance of this site comes from the fact that laterite soil is rich in Bauxite, and it is commercially always in demand. The major threat to this NGM is from the constructors who use the laterite site for bricks' construction.

\section{Varkala Cliff, Thiruvananthapuram, Kerala}

Varkala is the only place in the Southern part of Kerala where 'cliffs' are found. These cliffs are adjacent to the Arabian Sea. The entire cliff runs down with sedimentary formations in it. These Cenozoic sedimentary cliffs are commonly known as 'Varkala Formations'. Varkala also happens to be home to a temple that is more than 2000 years old. This is the famous tourism spot of Janardana Swami Temple. The varkala cliff is made up of beds of sands and beds of shale. Along with a thin seam of lignite which make this a good spot for natural vegetation and hence natural springs and scattered vegetation is common to the area.

The Varkala Cliff is adjacent to the sea and has a beach which offers a lot of tourism in this part of Kerala specifically. Sports like paragliding are quite common in the area apart from other water sporting activities. Heavy tourism activity, while very good for businesses locally, have led to poor disposal of garbage, ill-treatment of waste and other related problems. A simple sensitivity marketing for the consumers of this place will surely improve the situation.

\section{Lonar Lake, Buldana District, Maharashtra}

The lonar lake in Maharashtra is another intriguing site for tourists. It is almost a circular lake formed due to a crater impact millions of years ago. The meteorite impacted on the Deccan Basaltic rocks of the Cretaceous age. A meteorite is obtained from naturally orbiting in space that survives the impacts that are generated when it passes through the Earth's atmosphere. What makes this site really unique is the fact that not a lot of places in the world can boast a lake made out of a crater hole, only 130 terrestrial craters are universally recognized currently. The average diameter of the lonar lake stands at $1.7 \mathrm{~km}$, the average rim height is of 40 meters and the depth of the lake is nearly 250 meters. The central portion of the lake also has saline water accumulation. The lonar lake is $90 \mathrm{~km}$ south east of the buldana district.

Something that regularly attracts a lot of geologists and scientists from around the world is the fact that it is the third largest crater impact site in the world. By using thermoluminescence, the crater is dated to be $570000 \pm 47000$ years old. The visitors can really enjoy this geological site, as it isn't too difficult for common man to understand the cause of formation of the lake (meteorite impact) and it is an intriguing site for geologists, scientists and academicians as well.

\section{Ophiolite Rocks, Nagaland}

Nagaland is a mountainous region in north-eastern part of India. The Naga-Hills reach a height of around 4000 meters and are situated at the border of Myanmar and India. The ophiolite rocks are a section of the Earth's oceanic crust. These rocks are usually exposed to above sea level conditions and are often emplaced into continental's crust. This rock structure is greenish in colour and is found in abundance in the Naga hills of Nagaland.

\section{Pillow Lava, Iron ore belt, Nomira, Keonjhar District, Orissa}

Another pillow lava structure which is well preserved with a maximum thickness of the individual pillows at $2 \mathrm{~m}$ by $1 \mathrm{~m}$. The shape of the pillows is elliptical. The pillow lava vesicles are filled with quartz and the lava is medium grained in nature. Pillow lavas occur when lava is cooled rapidly under water, this results in the formation of a new kind of oceanic crust. The presence of pillow lavas in an area is also proof of the fact that water is present in that part of Earth. This site is more appealing to the scientists, geologists and people associated or working with relatable fields, as opposed to general public. 
The site lies very close to the road and in case of expansion of railways or roadways the site will face serious issues. Also, there is a lack of proper signage displays around this site.

\section{Stromatolite Bearing Dolomite or Limestone of Buxa Formation at Mamley, Near Namchi, Sikkim}

This stromatolite park is located in the Indian state of Sikkim which is bordered by Bhutan, Tibet and Nepal from three sides. The rocks belonging to the Carboniferous or the Purana age are represented in the Buxa formation. The Buxa formation include rocks, like shale, quartzite and dolomite, the last being the most frequent, predominant, and representative of the geological sequence under study. It is hard, compact, massive and thinly bedded. The Buxa group of rocks occur between the Permo-Carboniferous Gondwana and the PreCambrian Dating. It is separated from these two formations by thrusts. The Buxa set in approximately at the north-eastern boundary of India marks a very tectonically disturbed area and it constitutes a less competent geological formation against landslides. This site is very appealing for scientists and geologists. Moreover, regular tourists can also enjoy the beauty that this state has to offer to them in forms of rich biodiversity.

\section{Gossan, Rajpura, Rajsamand District, Rajasthan}

The rocks of the Rajpura-Dariba-Sindersar Khurd-Bethumbi Surawas area are known to belong to the precambrians (which is the earliest part of Earth's history that we know of). These sets of rocks rest proudly on the Aravallis and also equivalent to the Aravalli Supergroup of rocks (Ranawat et al., 2016). The age for basement gneiss is Meso-Archean and age for intrusive Untala granite is Neo-Archean. This gossan eventually led to the re-discovery of Rajpura- Dariba mineralized zone (Yadav et al., 2016). The zone has formed due to pervasive oxidation and chemical weathering of the sulphides that are present in the area. The gossan boasts a variety of colours including brown, dark brown, greenish blue, grey, white and also reddish brown. It also has different kinds of boxworks, which are essentially uncommon types of mineral structures that are rare but found in caves and environments that are erosive.

\section{Nepheline Syenite, Kishangarh, Ajmer District, Rajasthan}

The nepheline syenite site is placed along the core of an antiform of metamorphites that are present in the Aravalli craton. This NGM is dated 1590 million years to 1910 million years old.

\section{Sendra Granite, Pali District, Rajasthan}

Nature is the best sculptor and this NGM is a representative of that fact. The Sendra granites of the Pali district in Rajasthan were formed nearly 900 million years ago and is a set of plutonic igneous rocks. They also intrude in the Delhi supergroup of metasedimentary rocks (Ranawat et al., 2016). Over millions of years the natural phenomenon of weathering and erosion have constantly acted on the granite and this has created marvellous structures in the place.

\section{Barr Conglomerate, Pali District, Rajasthan}

Another geologist friendly spot in the Pali district, this conglomerate is composed of quartzite and rare granite pebbles, which then seem to be combined in some form of grained pelitic matrix. This structure rests conformably on Barr vicinity. A conglomerate is particularly of interest to geologists as it helps subdividing geologic history on the basis of various sedimentary breaks. The weathering process of millions of years have stretched the pebbles in this place by 20 to 30 times of their original dimensions (Ranawat et al., 2016).

\section{Jodhpur Group, Malani Igneous Suite Contact, Jodhpur, Rajasthan}

The Jodhpur group of Malani rocks is a geological feature that represents the last phase in the Precambrian age in the Indian subcontinent when igneous activity was non-dormant. This group of rocks lies at the bottom of the famous Mehrangarh Fort in the heart of Jodhpur city and forms a vivid picturesque for any admirer. Rajasthan was formerly divided into two regions namely Mewar and Marwar. Malani was the name of a district in the former state of marwar. This was one such place in the region of Marwar where volcanic rocks were found and hence the name Malani bed rocks. The name had undergone several changes over the years: Malani Beds (1877), Malani Volcano Series (1902), Malani System (1933), The Malani Granite and Volcanic Suite (1968), and finally it came to be known as Malani Igneous Suite. The place is integral to the Thar desert in Rajasthan which has a total area of 45000 square kilometre.

\section{Welded Tuff, Jodhpur District, Rajasthan}

Another NGM in the Jodhpur district of Rajasthan, the welded tuffs are a product of emanations that spurted millions of years ago from the volcanic vents and then were carried down by air till they finally settled down. When this air cooled down it gave rise to terraces and columnar structures. These structures are composed of glass, quartz and also feldspar. The malani rhyolites essentially comprise of welded tuff, pyroclastic rocks and various coloured rhyolites such as green, grey, pink, maroon, brown and purple. The terraces and the columnar structures are hexagonal to rectangular in shape and stretch to nearly 30 meters in dimensions. 


\section{Akal Wood Fossil Park, Jaisalmer District, Rajasthan}

An NGM marked amidst the desert city of Jaisalmer that is surrounded by the thar desert from various sides. Akal wood fossil park is spread across a total area of 21 hectares and gets its name from its location that is in the Akal village situated 18 $\mathrm{km}$ from Jaisalmer. The terrain around the village is rocky and barren. This fossil park has the potential to be turned into a geological park as well. It boasts the fossils and footprints of pterosaurs near the Thaiyat area. The park consists of fossils of wood from the Jurassic period. Majorly found species are of petrophyllum, ptyllophylum, equisetitis, dicotyledonous wood and also gastropod shells (Ranawat et al., 2016). There is a total of 25 petrified tree trunks in the area and they lie across stretching about 13 meters in length and 1 meter in width. The fossils present in the area are dated to be 180 million years old. GSI declared this site as an NGM in 1972 itself. This site has a great potential to be transformed into a Geopark and add more value to it.

\section{Great Boundary Fault at Satur, Bundi District, Rajasthan}

The Vindhyan Basin of India is a Cratonic Basin which has an Archaean basement. These well-adjusted sections of Vindhyan sedimentation are seen across the country in various states be it in Uttar Pradesh, Madhya Pradesh, Bihar and Rajasthan. In Rajasthan the Northwestern margin of Vindhyan Basin has a major fault which extends itself over a distance of nearly 400 $\mathrm{km}$ from Chittorgarh to Machilpur. This fault came to be known as The Great Boundary Fault of Rajasthan and is considered as the limit of the Vindhyan sedimentation The Great Boundary Fault for decades now has been considered as an enigma of geology in Rajasthan. It is partly because the frontal margin of the Vindhyan has been eroded in most of the sections, erasing the primary signatures of the fault plane and partly due to the fact that the geometry of the failure surface has been modified by later secondary wrench faulting.

\section{Stromatolite Park, Bhojunda, Chittorgarh District, Rajasthan}

This NGM shows off massive limestone from the lower Vindhyan age. The stromatolite rocks are structures that are come in existence when bluish-green algae attach itself to the carbonate particles. This attachment forms a mat like structure. Because of the life activity and the sediment tapping and binding ability of the algae the stratiform which is formed is both columnar and nodular in structure. The unique fact that can be gathered from stromatolites is that they represent one of the earliest life forms on the planet. The location of the Bhojunda village lies 7KM south-west from Chittorgarh, which hosts one of the best exposures of the stromatolites (Ranawat et al., 2016).

\section{Stromatolite Park, Jhamarkotra, Udaipur District, Udaipur, Rajasthan}

This site has large and rich deposits of phosphorite which is also associated with stromatolite. This site is of levelled strategic importance because just like the Stromatolite park in Chittorgarh district this place too is a proof of the earliest forms of life on the planet. The rock phosphates present in this region belong to the Precambrian Aravalli Supergroup of rocks. The phosphorite is present in the phosphate rocks that appear as limestone which appears bluish-grey in colour and is of different shapes and different sizes.

This NGM is present in the Udaipur district of Rajasthan and is nearly $25 \mathrm{~km}$ away from the city of Udaipur and can be easily approached by the Salumbar road which links the Jhamerashwara temple (Ranawat et al., 2016).

\section{Charonockite, St. Thomas Mount, Chennai, Tamil Nadu}

Charonockite is a basic exposure of quartz, feldspar and hypersthene rock in the presence of two pyroxene undergoes metamorphism. Interestingly, Job Charnock (who founded the city of Kolkata) has his tomb made up of this type of stone and hence the name Charonockite is derived from that point. This rock is very important from a geological perspective as it helps the scientists understand the crustal evolution of the Earth (Subramanian et al., 2001; Selvan et al., 2001), and the manner in which a site filled with charonockite rocks helps the process is by the formation of the very rock itself. The rock is formed under high temperature but dry conditions.

\section{National Fossil Wood Park, Tiruvakkarai, Tamil Nadu}

In this wood fossil park, nearly 200 tree trunks are placed horizontally which are embedded in the Cuddalore Sandstone of Mio-Pliocene age (20 million years ago). The fossils range anywhere between 3 meters to 15 meters in length and up to 5 meters in width.

\section{National Fossil Wood Park, Sattanur, Tamil Nadu}

This fossil wood park hosts large tree trunks of the Upper Cretaceous age (100 million years old). These are petrified tree of various sizes that can be found in the area. The land vegetation in the area is that of the confiners. Confiners is a variety of non-flowering trees that were heavily dominant in the area millions of years ago and still continue to dominate the area. The fossilised tree trunks in this national park boast length of up to 18 meters to 20 meters in length and once again 1 meter nearly in thickness.

32. Karai Formation with Cretaceous fossils along Karai, Perambalur District, Tamil Nadu 
This NGM is located in Badlands. Badlans are a type of dry terrain where sedimentary rocks and clay have eroded due to weathering by water or wind.

This Cretaceous sedimentary rock succession is known for fossils of Mid and Late Cretaceous marine animals (from 100 to 60 million years ago).

Fossils of different marine invertebrates such as ammonites, nautiloids, belemnites, worm tubes, pelecypods, gastropods, oysters, etc. can be found in the fossil park.

\section{RECOMMENDATIONS FOR PRESERVATION OF THESE SITES}

1. A lot of the sites fall under the purview of illegal miners who destroy the natural beauty of these places. The mineral wealth while important from an economic activity perspective, should not be confused with exploitation of natural resources of the area (Gill et al., 2016). Hence, stringent actions should be taken against miners who exploit these sites.

2. Installation of proper signage boards along with cleaning activities for these sites should happen periodically, at the same time the area that leads up to these sites should also be maintained, and cleared of any blockages.

3. A lot of these sites get affected by expansion of roads, construction of homes, or expansion of the railways network. Again, these sites should be subjected to 'Buffer Zones' and not treated as any other patch of land. Re-routing the projects of expansion/ construction a little away from these sites can help preserving them.

4. Proper fencing and demarcation of these sites should be done by the Government with the help of Geological Survey of India (GSI).

5. Water bodies around these areas get affected by industrial waste, improper sewage treatment or garbage disposal, such activities can easily be regulated as well.

\section{RECOMMEDATIONS FOR DEVELOPING \& MARKETING THESE SITES}

1. Capturing the essence of the 'Digital Age', these sites should be promoted using various social media platforms, which are great for digital marketing of these sites and creation of awareness about these sites. This also adds a level of credibility to these sites, along with a visible push from the 'Government of India' to promote these sites.
2. Proper flyers, brochures and websites should be created for these sites and circulated by the state. Even easier for the state would be to do this digitally, not only is that effective for 'Targeted Marketing' but can reduce the costs and environmental impact exceptionally.

3. Government can bring small amounts of private investment for these sites, to propel the aspects of tourism around these sites, and the private enterprises can benefit from a guaranteed return or a share of the pie from the business that is generated from these sites.

4. NGMs with an immediate need or ability to be converted into a Geopark should be identified and such projects should be launched by the Government at the earliest. This will also help display these sites on an international radar with the help of UNESCO's initiatives.

\section{CONCLUSION}

The importance of this paper or the key take-aways for the reader are three-pronged. Firstly, that it is critical to know about the geological diversity and richness that exists around us. Secondly, for the Government and the concerned authorities to realise the huge economic potential that can arise from these sites in a sustainable and eco-friendly manner. Thirdly, to induce a sense of care in the individuals of the society with regards to Geoheritage sites, geological features of our planet go through millions of years of development and formation and they can be easily tampered by human intervention. What we need at the moment is: "Information Supply", these sites can easily be noticed and be taken care of by local communities, state administration and central ministries, but the starting point for that is going to beawareness. Creating more awareness about these sites and supplying people with the information about these sites in order for them to realise the significant value that can be derived from these sites.

\section{ACKNOWLEDGEMENT}

I am thankful to Dr. Pushpendra Singh Ranawat for providing me with regular assistance during the shaping of this research paper. His views and thoughts have assisted me always.

\section{REFERENCES}

1. Ranawat, Dr. P.S. (2016). Geoheritage of Udaipur Region. Udaipur, Rajasthan: Kumbha Exclusives, (pp. 05-09).

2. Ranawat, Dr. P.S. (2016). Monograph on National Geological Monuments and Potential Geoheritage Sites of Rajasthan. Udaipur, Rajasthan: Kumbha Exclusives, (pp. 01-03) 


\section{International Journal of Engineering Applied Sciences and Technology, 2020 \\ Vol. 4, Issue 11, ISSN No. 2455-2143, Pages 224-231 \\ Published Online March 2020 in IJEAST (http://www.ijeast.com)}

3. INTACH (2016). A Monograph on National Geoheritage Monuments of India. Lodhi Estate, New Delhi: Indian National Trust for Art and Cultural Heritage, (pp. 12-19)

4. National Geographic, About Geotourism, accessed on $11^{\text {th }} \quad$ March, 2020, https://www.nationalgeographic.com/maps/geotouris m/about/

5. Karam, P.K. and Murty, V.N. (1997). Geology of Andhra Pradesh. Bangalore, Karnataka: Geological Society of India, (pp. 15-16)

6. Vasudev, V.N., Chandra Subhash, K.C. and Venkataramaiah, P. (1998). Bibliography of Indian Geology. Bangalore, Karnataka: Geological Society of India, (pp. 47)

7. Mahadevan, T.M., Arora, B.R. and Gupta, K.R. (2003). Indian Continental Lithosphere: Emerging Research Trends. Bangalore, Karnataka: Geological Society of India, (pp. 84-85)

8. Subramanian, K.S. and Selvan, T.A. (2001). Geology of Tamil Nadu and Pondicherry. Bangalore, Karnataka: Geological Society of India, (pp. 56)

9. Radhakrishna, B.P. and Vaidyanadhan, R. (1997). Geology of Karnataka. Bangalore, Karnataka: Geological Society of India, (pp. 78-80)

10. Sen, B.K. Indian Geoheritage, Geodiversity: Geosites and Geoparks. Research Paper: New Delhi, (pp. 1-3)

11. Gill,J.C. (2016, February). Geology and Sustainable Development Goals. Research Paper: British Geological Survey, (pp. 2-3)

12. Yadav, P.K. Geology of Rajpura-Dariba Group of Rocks. Research Paper: International Journal of Research and Innovations in Earth Sciences, (pp. 1-2)

13. Brilha, J. (2015, January 15). Inventory and Quantitative Assessment of Geosites and Geodiversity sites: A Review. Research Paper: The European Association for Conservation of Geological Heritage 2015, (pp. 1-2)

14. Department of Mining and Geology, Thiruvananthapuram (2016, November). District Survey Report of Minor Minerals (Except River Sand)-Malappuram District, (pp. 13)

15. Sahay, A. (2005, March). Tectonic History of the Great Boundary Fault, Rajasthan-A Thesis, (pp. 2123)

16. Singh, R.B. (2006). Geodiversity, Geographical Heritage and Geoparks in India. University of Delhi, Delhi, (pp. 11)

17. Lovelock, C., Wirtz, J. and Chatterjee, J. (2016). Service Marketing: People, Technology and Strategy $(8 E)$. Noida, Uttar Pradesh: Pearson India Education Services Pvt. Ltd., (pp. 45-59)

18. Kotler, P., Keller, K., Koshy, A., and Jha, M. (2013). Marketing Management: A South Asian Perspective
(14E). Noida, Uttar Pradesh: Dorling Kindersey (India) Pvt. Ltd., (pp. 139-147)

19. Cooper, D. and Schindler, P. (2005). Marketing Research: Concepts and Cases. India: Tata McGrawHill Education, (pp. 121-30)

20. Bowersox, D. and Cooper, M. (1992). Strategic Marketing Channel Management. India: McGrawHill Publishing Co., (pp. 239-241)

21. Easwaran, S. and Singh, S. (2006). Marketing Research: Concepts, Practices and Cases. India: Oxford University Press, (pp. 55-59) 